\title{
Rydwan celtycki w dobie wojen cezariańskich
}

\begin{abstract}
Abstrakt: Wykorzystywanie rydwanu w boju miało długą tradycję na starożytnym Bliskim Wschodzie, lecz nie w północnej Europie. Na jej wielu obszarach wozy bojowe i konie zaprzęgowe składano do grobu razem z arystokratycznymi przywódcami. Rydwany służyły w Europie do ok. $100 \mathrm{r}$. p.n.e., ale w Brytanii wykorzystywano je znacznie dłużej. Ich prędkość i zwrotność generowały Rzymianom poważne problemy. Nie posyłano ich do szarży przeciw liniom wroga. Wojownik walczył z rydwanu przeciw konnicy, lecz zazwyczaj schodził z pudła i walczył pieszo zarówno z jazdą, jak i piechotą. W Brytanii wiele koni wielkością przypominało współczesne pony rasy Dartmoor i nadawało się jedynie do zaprzęgania w rydwanach. Galowie z kontynentu natomiast nauczyli się hodować większe konie, które mogły dźwigać na grzbiecie wojownika w pełnym uzbrojeniu. Rydwany Brytów raczej nie posiadały kos. Nie ma żadnych dowodów archeologicznych na istnienie takich rydwanów w Brytanii.
\end{abstract}

Słowa kluczowe: biga, kuc, wojownicy, woźnice, rydwan z kosami, rydwan bojowy

Jednym z ciekawszych aspektów wojskowości celtyckiej, szczególnie w Brytanii, na przełomie er było wykorzystanie na szeroką skalę rydwanów bojowych. Jest to o tyle frapujące, że starożytne armie zrezygnowały z nich stosunkowo dawno, a teren, na którym używali ich Brytowie, nie sprzyjał temu.

Kolebką rydwanu było pogranicze stepu i cywilizacji na Bliskim Wschodzie. Pierwsze konstrukcje zastosowane bojowo miały postać masywnych czterokołowych wozów zaprzężonych w onagry. Ukazano je na słynnym Sztandarze z Ur (2500 r. p.n.e.) oraz w grobowcu króla Pabilisaga (2250 r. p.n.e.) $)^{1}$ Sumerowie, twórcy pierwszej cywilizacji mezopotamskiej, skrzyniową konstrukcję pudła wozu, mieszczącą dwie osoby stojące jedna za drugą, zaopatrzyli w pełne koła trójsegmentowe. Podwyższony front skrzyni mieścił futerał na potrzebne wyposażenie w rodzaju włóczni, oszczepów bądź czekana. Brak możliwości skręcania pojazdu z powodu osi sztywno mocowanych do jego podłogi oraz mało efektywny sposób powożenia

\footnotetext{
${ }^{1}$ J.W. Hamblin, Warfare in the Ancient Near East to 1600 BC, Routledge 2006, s. 133.
} 
(zwierzętami powodowano za pomocą lejcy wiązanych do kolczyka w chrapach) czynił z rydwanu problematyczne narzędzie walki².

Prawdziwy przełom $\mathrm{w}$ tym względzie nastąpił $\mathrm{w}$ drugim tysiącleciu przed naszą erą, kiedy pojawił się lekki, jednoosiowy pojazd z kołami szprychowymi. Zaprzężony był w parę koni, a z woźnicą i łucznikiem na pudle pełnił funkcję mobilnej platformy strzeleckiej. Do działań wojennych wprowadzili go prawdopodobnie Huryci, którzy jako pierwsi połączyli dużą mobilność wozu z możliwością prowadzenia z niego intensywnego ostrzału. Taki sposób walki w istotny sposób przyczynił się do powstania pierwszych imperiów. Te zaś ponieważ dysponowały odpowiednimi środkami, finansowały hodowlę koni zaprzęgowych, ich ułożenie, szkolenie załóg oraz budowę rydwanów. Mocarstwa epoki brązu, takie jak Egipt, Mitanni czy państwo Hetytów, utrzymywały w linii $2-3$ tysiące wozów, podczas gdy małe królestwa miały ich najwyżej kilkaset ${ }^{3}$. Tak było w świecie egejskim, gdzie - w przeciwieństwie do otwartych przestrzeni Bliskiego Wschodu - możliwości wykorzystania rydwanu były drastycznie ograniczone z uwagi na ukształtowanie terenu i brak dróg. Mimo to zarówno lekka dwukołowa biga, jak i czterokołowy wóz stanowiły jedyny środek transportu wojowników na pole bitwy, począwszy od XVI wieku p.n.e. do końca okresu geometrycznego ${ }^{4}$.

Taka rola tych pojazdów, jak również niesprzyjające warunki terenowe, w których się poruszały, upodabnia je do rydwanów celtyckich. Podobieństwo to dotyczy także ciężkich wozów dwuosiowych pełniących funkcję pojazdów ceremonialnych w obrządku grzebalnym. U Greków we wczesnym okresie wykorzystywano je jako platformę transportującą zwłoki arystokraty na miejsce pochówku; u Celtów zaś stanowiły element wyposażenia grobowego, swoiste mary, na których zmarły spoczywał w pełnym rynsztunku bojowym ${ }^{5}$. W skazuje to na rytualny związek wojownika ze środkiem transportu, który symbolicznie wiózł go w zaświaty i tam służył mu dalej. Pośrednio potwierdza to tezę o stepie euroazjatyckim jako kolebce Celtów i wiąże ich z terenami południowej Rosji, gdzie udomowiono konia. Samych Celtów lub ich przodków uważa się również za twórców transportu kołowego w Europie, znawców hodowli koni i zamiłowanych kawalerzystów. Na dowód tego

2 S. Anglim et al., Fighting Techniques of the Ancient World, London 2002, s. 80. Zwierzęta pobudzane do ruchu ruszały nagle z pełną prędkością i co najwyżej można było, z dużym trudem, je wyhamować, o jakimkolwiek sterowaniu nie było mowy.

${ }^{3}$ J. Oorthuys, Warfare in the Ancient Near East, „Ancient Warfare” 2008, 2, 5, s. 7; M. van de Mieroop, Historia starożytnego Bliskiego Wschodu, przeł. M. Komorowska, Kraków 2008, s. 147, 151; A. Ferrill, The Origins of War, London 1985, s. 40; R. Castleden, Wojna trojańska, przeł. B. Tkaczow, Warszawa 2008, s. 123; A. Millard, Going to War in Ancient Egypt, London 2000, s. 11.

${ }^{4}$ R. D’Amato, Bronze Age Greek Warrior 1600-1100 BC, Oxford 2011, s. 46; Idem, Early Iron Age Greek Warrior 1100-700 BC, Oxford 2016, s. 42.

${ }^{5}$ R. D’Amato, Bronze Age Greek Warrior..., s. 46; Idem, Early Iron Age Greek Warrior..., s. 43; T. Newark, Ancient Celts, Concord 1997, s. 6; R.L. Jimenez, Caesar against the Celts, Kent 1996, s. $34-35$. 
przywołuje się zapożyczenie przez Rzymian wyrazu carrum na określenie pojazdu kołowego; od tego słowa pochodzą angielskie: cart, car czy carriage ${ }^{6}$.

$\mathrm{W}$ początkach epoki lateńskiej pojawił się lekki, dwukołowy rydwan, który prawdopodobnie wyewoluował z cięższego, czterokołowego wozu, zastępując go również w obrzędach funeralnych. Nowa jakość polegała na stworzeniu lekkiej platformy na kołach szprychowych, zaprzężonej w parę kuców hodowanych w dużych gospodarstwach rolnych w późnej epoce żelaza. Zwierzęta te wyglądem przypominały kuce rasy Dartmoor, a ich wysokość w kłębie nie przekraczała $125 \mathrm{~cm}^{7}$. Były silne, wytrzymałe, praktycznie żywiły się byle czym. Wartość tych zwierząt nie była duża, w przeciwieństwie do rasowych, pełnokrwistych rumaków bojowych z Bliskiego Wschodu wartych majątek.

Przeznaczeniem wozów pierwotnie mogła być walka z wrogimi rydwanami, ale nie ma na to dowodów. Nie służyły też jako platforma strzelecka, gdyż nie ma wzmianki o łucznikach na rydwanach, chociaż łucznictwo przeżywało w Galii w okresie powstania Wercyngetoryksa renesans. Tak taktykę walki rydwanów opisał Cezar w dziele $O$ wojnie galijskiej: „najpierw objeżdżają nieprzyjaciela ze wszystkich stron dookoła i zasypują go pociskami [oszczepami - B.S.], w dodatku już samym strachem wywołanym rozpędzonymi końmi oraz hurkotem kół powodują częstokroć zamęt w szykach, a gdy im się uda wtargnąć między oddziały konnych, zeskakują z wozów i walczą spieszeni”, dalej konkluduje: „łączą więc w bitwach szybkość jazdy i wytrwałość piechoty"8. Jak słusznie zauważa Peter Harrison, celtyckie rydwany nie były przeznaczone do szarży na zwarte formacje wroga, lecz pełniły funkcję platformy dla oszczepników i transportowały arystokratycznych wojowników na linię walki i z powrotem 9 . Przywodzi to na myśl homeryckie opisy walk pod murami Troi, gdzie w podobny sposób rydwany użytkowali Achajowie. Kwestia ta wywołuje kontrowersje i prowadzi do podważania wiarygodności źródeł pisanych, a nawet do oskarżeń pod adresem Homera o brak orientacji w tym temacie, spowodowany sporym dystansem czasowym dzielącym opisywaną epokę i czasy, w których żył poeta ${ }^{10}$.

Wszystko wskazuje jednak na to, że nie ma podstaw do odrzucenia przekazów starożytnych, można co najwyżej pokusić się o interpretację szczegółów natury taktycznej. I tak Tim Newark twierdzi, że wozów używali jedynie wybitni

\footnotetext{
${ }^{6}$ R.L. Jimenez, Caesar against the Celts..., s. 34-35.

7 T. Newark, Ancient Celts..., s. 6; R.L. Jimenez, Caesar against the Celts..., s. 34-35; J. Wileman, Warfare in Northern Europe before the Romans, Barnsley 2014, s. 138.

${ }^{8}$ Caes., Bell. Gall. IV, 33 (przeł. E. Konik, W. Nowosielska-Konikowa).

${ }^{9}$ P. Harrison, Great Battles of the Ancient World, London 2004, s. 127. Rydwany starożytne nigdy nie szarżowały na zwarte formacje piechoty, gdyż konie miały naturalną skłonność do skręcania przed zderzeniem z ludzką masą, a samo zderzenie prowadziło do wyrzucenia załogi prosto w szyki nieprzyjaciela.

${ }_{10}$ M. Riemschneider, Od Olimpii do Niniwy w epoce Homera, przeł. F. Przebinda, Warszawa 1969, s. 55-56.
} 
wojownicy w celu spektakularnego wjazdu na plac boju, po czym je odsyłali. Sami zaś dosiadali uprzednio przygotowanych koni i wraz ze świtą podejmowali walkę. Badacz dopuszcza wykorzystanie rydwanów jedynie w końcowej fazie bitwy - w pościgu za pobitym wrogiem lub pośpiesznej ewakuacji w przypadku klęski ${ }^{11}$. Kłóci się to $\mathrm{z}$ przekazami historiograficznymi, na przykład z opisem Liwiusza bitwy pod Sentinum w 295 roku p.n.e., gdzie „zbrojny nieprzyjaciel stojąc na wozach wojennych i zwykłych, nadjechał z ogromnym hukiem koni i kół, spłoszył konie jazdy rzymskiej nie przywykłe do takiego hałasu. W przerażeniu wprost szaleńczym rozproszyła się zwycięska jazda [...] i mnóstwo żołnierzy z pierwszego szeregu stratowały konie i wozy pędzące przez środek szeregów" 12 . Wtóruje mu Pomponiusz Mela, podając, że „Brytowie [...] walczą nie tylko konno lub pieszo, ale też z dwukonnych rydwanów”'13. Także Diodor pisze, iż „plemiona kaledońskie podtrzymywały tradycję walki na rydwanach"14, a Strabon wspomina, że „w bitwach Brytowie głównie wykorzystują rydwany jak Celtowie” ${ }^{15}$. Nawet Cyceron ostrzega Trebacjusza Testę, by postarał się „zabezpieczyć siebie w Brytanii od napaści wojowników z wozów"16. Jak wynika z przytoczonych opisów, określanie rydwanów mianem taksówek dowożących wojowników na pole bitwy jest nie do końca uprawnione; ich rola zmieniała się wraz z upływem czasu i była dostosowana do rozwoju sytuacji taktycznej ${ }^{17}$.

Na kontynencie rydwany stosunkowo szybko wyszły z użycia, ostatnia bitwa, w której pojawiły się w masie, to starcie pod Telamonem w 225 roku p.n.e., gdzie ustawione na skrzydłach szyku nie odegrały znaczącej roli. W następnym okresie ich miejsce $\mathrm{w}$ armiach plemiennych zajęła kawaleria, która jako kontyngenty najemne trafiła również w szeregi wielu armii świata śródziemnomorskiego. Było to na tyle ciekawe zjawisko, że Alain Deyber próbuje ująć je w ramy chronologiczne. Twierdzi, że rydwany wyszły z linii między 121 a 58 rokiem p.n.e. z powodu nieudokumentowanej, jak to określa, inwazji Cymbrów i Teutonów pod koniec II wieku p.n.e., a następnie Swebów we wschodniej Galii w latach 70. I wieku p.n.e. Najeźdźcy używali wyłącznie kawalerii, co wymusiło rezygnację z rydwanów dla wyrównania szans i wypracowanie nowej taktyki walki ${ }^{18}$. Teoria jest kusząca, lecz

${ }_{11}$ T. Newark, Warlords, London 1996, s. 162; Idem, Ancient Celts..., s. 6; M.N. Faszcza, Rzymskie inwazje na Brytanię 55-54 p.n.e., Zabrze 2012, s. 42. Rydwany atakowały piechotę z dystansu.

${ }_{12}$ Liv. X, 28 (przeł. A. Kościółek). Zwykłe wozy były zapewne czterokołowe, tutaj określane jako essedae carrique.

${ }_{13}$ Pomp. Mel. III, 6 (przeł. M. Golias).

${ }^{14}$ Diod. V, 21 (przeł. N. Łajszczak).

15 Strab. IV, 5, 2 (przeł. N. Łajszczak).

${ }^{16}$ Cic., Fam. VII, 6 (przeł. K. Kumaniecki).

${ }_{17}$ Rome and her Enemies, ed. J. Penrose, Oxford 2008, s. 137. Jeszcze podczas powstania Boudiki w 61 roku, w bitwie przy drodze do Watling, rydwany ustawione były przed szykiem Brytów.

18 A. Deyber, Les Gaulois en guerre, Paris 2009, s. 324. 
pozbawiona podstawy źródłowej; bardziej wiarygodna wydaje się ta wskazująca na postępy w hodowli konia bojowego na kontynencie, do czego doszło w wyniku kontaktu z ludami stepowymi Europy Wschodniej. Poprawa gatunku koniowatych i pojawienie się dużych - mierzących 145-150 cm w kłębie - osobników, które były w stanie nieść na grzbiecie ciężkozbrojnych arystokratów, pozwoliło wyeliminować rydwany ${ }^{19}$.

W Brytanii natomiast rydwany pozostały głównym środkiem transportu aż do podboju rzymskiego. Wynikało to zapewne z braku realnego zagrożenia zewnętrznego i skupieniu się Brytów na mniej intensywnych walkach międzyplemiennych, którym daleko było do wojny totalnej. Nie bez znaczenia była też prowadzona na tym obszarze na dużą skalę hodowla kuców, dostarczająca tanich w utrzymaniu i wytrzymałych koni zaprzęgowych. Ponadto w społecznościach wyspiarskich rydwanów używała elita, traktując je jako symbol przynależnego im statusu. Wpływało to na relacje między członkami załóg, w których życie wojowników (clientes) spoczywało w rękach woźniców (aurigae) i zależało od ich umiejętności i odpowiedzialności. Tacyt nadmienia w żywocie Agrykoli, że u niektórych plemion powozi dostojniejszy, a klienci walczą, Diodor zaś pisze, że woźnice to wolni ludzie wybrani spośród biedniejszych warstw i zatrudniani jako nosiciele tarcz $z^{20}$. Niewątpliwie przejawem brawury i popisem sprawności powożącego był przejazd $\mathrm{z}$ dużą prędkością nad urwiskiem, nagłe wyhamowanie i nawrót niemal w miejscu czy też bieganie po dyszlu w trakcie jazdy ${ }^{21}$. Chociaż w komentarzach ten ostatni przypadek uzasadnia się dążeniem do zwiększenia zasięgu miotanego oszczepu, to równie dobrze działanie to mogło mieć na celu dociążenie koni, a tym samym poprawienie sterowności pojazdu w krytycznym momencie. Jedno jest pewne, woźnice wrzeszcząc, gnali na złamanie karku, by jak najszybciej spotkać się z wrogiem ${ }^{22}$.

Na tej podstawie wnioskować można o solidnej budowie rydwanów. Świadczy o tym również egzemplarz zrekonstruowany przez Wernera Bodensteinera - długi na $4,10 \mathrm{~m}$, szeroki na $1,45 \mathrm{~m}$ i wysoki na $1,50 \mathrm{~m}$. Platforma pudła o wymiarach $1,40 \times 1,00 \mathrm{~m}$ zaopatrzona była $\mathrm{w}$ dyszel długości $2,70 \mathrm{~m}$, a oś mierzyła $1,35 \mathrm{~m}$. Koła miały $0,9 \mathrm{~m}$ średnicy, a całość ważyła $110 \mathrm{~kg}^{23}$. Dyszel wychodził spod platformy i wznosił się na wysokość $1,15 \mathrm{~m}$, a na jego końcu mocowano poprzecznie podwójne jarzmo. Dwie boczne ściany pudła z uwagi na ciężar konstrukcji musiały być lekkie, dlatego w wyobrażeniach numizmatycznych mają postać plecionki wiklinowej w kształcie półokrągłym lub podwójnej arkady z giętego drewna. W celu

\footnotetext{
19 Ibidem, s. 300.

${ }^{20}$ Tac., Agr. 12, 1 (przeł. S. Hammer); Diod. V, 29.

${ }^{21}$ Caes., Bell. Gall. IV, 33.

${ }^{22}$ G. Banfi, L'Armamento dei Celti, Rimini 2004, s. 74.

${ }^{23}$ F. Mathieu, Le guerrier gaulois, Paris 2012, s. 45-46. Tego typu rydwan pozwalał pokonać dziennie dystans do $60 \mathrm{~km}$.
} 
pełnej kontroli nad zaprzęgiem lejce prowadzono brązowymi, mocowanymi do jarzma pierścieniami, które same w sobie były małymi dziełami sztuki ${ }^{24}$. Woźnica i wojownik stali na podłodze prostopadle do dyszla, przesunięci maksymalnie na tył, aby odciążyć końskie karki pod jarzmem. $\mathrm{Z}$ analizy ikonograficznej wynika jednak, że często zdarzało się, iż woźnica siedział lub klęczał z przodu, na styku pudła $\mathrm{z}$ dyszlem, ale dotyczyło to, jak się wydaje, rydwanu bez ścianki przedniej. Stąd sugestia W.W. Taratorina wskazująca na podobieństwo wozu celtyckiego do rydwanu elamickiego. Również dlatego, że dyszel był mocowany do osi usytuowanej centralnie pod pudłem ${ }^{25}$. Wiele cennych wskazówek odnoszących się do szczegółów konstrukcyjnych zgromadzono przy okazji rekonstrukcji rydwanu z Wetwang Slack, zleconej przez BBC w 2001 roku, a nadzorowanej przez British Museum. Jak się okazało, miał on prostokątną ramę drewnianą z rozpiętą na niej skórzaną plecionką jako podłogą, amortyzującą (pionowe) wstrząsy podczas jazdy. Zawieszona była na sznurach w kształcie litery $\mathrm{Y}$, które u góry wiązano do bocznych pałąków, a na dole do łukowatych poprzecznych belek. Pozwalało to na amortyzację również ruchów poziomych, dając w pełni stabilny pojazd o małym promieniu skrętu, co umożliwiało celne miotanie oszczepów w biegu i sprawny zeskok z pudła z mieczem i tarczą w ręku' ${ }^{26}$.

Niewątpliwą zaletą konstrukcji były lekkie wieloszprychowe koła o średnicy od $0,8 \mathrm{~m}$ do $1,00 \mathrm{~m}, \mathrm{z}$ żelazną jednoczęściową obręczą i metalową lub drewnianą piastą. Na kontynencie wieniec koła wykonywano z jednego kawałka giętego drewna, ze ściętymi końcami zachodzącymi na siebie, który łączył się z piastą szprychami usztywnionymi metalowymi klamrami w kształcie litery U. Na obwodzie okuty był metalową obręczą. Obręcz nabijano na gorąco, by po wystygnięciu mocno ściągała drewniane elementy. W Brytanii często używano kół z wieńcem wykonanym z kilku elementów łączonych ze sobą czopami. Przykładowo koło z Holme Pierrepont ma 6 sekcji i 12 szprych. Inny egzemplarz znaleziony w Bar Hill ma 11 szprych toczonych z wierzby, jednoczęściowy wieniec z jesionu i piastę wykonaną z wiązu ${ }^{27}$. Koła mocowano na osi za pomocą specjalnych zatyczek w formie klinów, artystycznie wykonanych z metalu i bogato zdobionych. Skłonność do dekoracji rydwanów u Celtów była powszechnie znana w starożytności, nie dziwi więc uwaga Lukana sugerująca, że Belg to „znakomity woźnica na pokazowym rydwanie”28. Podobnie Florus wspomina władcę Arwernów, pisząc, że „podczas triumfu [Gnejusza

\footnotetext{
${ }^{24}$ W.E. Ritchie, J.N.G. Ritchie, Celtic Warrior, Buckinghamshire 1985, s. 32-33.

25 W.W. Taratorin, Konnica na wajnie. Istorija kawalerii s drewniejszych wremion do epochy napoleonowskich woin, Minsk 1999, s. 23.

${ }^{26}$ J. Wileman, Warfare in Northern Europe..., s. 138; J.H. Crouwel, Chariots and other wheeled vehicles, Oxford 2012, s. 212.

${ }^{27}$ G. Banfi, L'Armamento dei Celti..., s. 67; J. Wileman, Warfare in Northern Europe..., s. 138; W.E. Ritchie, J.N.G. Ritchie, Celtic Warrior..., s. 33.

${ }^{28}$ Luc., Phars. I, 426 (przeł. M. Brożek).
} 
Domicjusza Ahenobarbusa, konsula z 122 r. p.n.e. - B.S.] nic tak nie rzucało się w oczy jak sam król Bituitus w swoim różnobarwnym orężu na srebrnym wozie, jakby brał udział w walce"29.

Przewaga Rzymian w walce $\mathrm{z}$ rydwanami wroga znalazła odbicie w numizmatyce. I tak denar L. Hostiliusa Saserny przedstawia uzbrojonego wojownika stojącego z szeroko rozstawionymi nogami wspartymi o ściany boczne pudła; ściany te mają kształt podwójnej arkady. Wojownik zwrócony jest tyłem do siedzącego z przodu woźnicy, który pogania konie, prawdopodobnie z metalowymi naczółkami ozdobionymi fantazyjnymi rogami. Natomiast na monecie Cezara widnieje wyprzęgnięty rydwan z tarczą i włócznią jako trofeami dla przypomnienia ludowi rzymskiemu jego dokonań w Brytanii3 ${ }^{30}$.

Pojazdy Brytów fascynowały Rzymian do tego stopnia, że pojedyncze ich egzemplarze przywiezione jako zdobycz wojenna przekazywano $\mathrm{w}$ prezencie tak było w przypadku Elianusa, który obdarował rydwanem poetę Marcjalisa. Wykorzystywano je również $\mathrm{w}$ pokazach walk gladiatorów, czasami z żeńską osadą ${ }^{31}$.

Najwięcej emocji budziły jednak — i budzą nadal — rydwany z kosami używane rzekomo przez Brytów. Autorzy antyczni określają je mianem covinni i wyraźnie odróżniają od rydwanu zwanego carpentum czy rydwanu bojowego - essedum ${ }^{32}$. Zachowały się dwie relacje autorów antycznych dotyczące bojowego wykorzystania tego typu rydwanu. I tak, Pomponiusz Mela twierdzi, że Brytowie „walczą nie tylko konno i pieszo, ale i na rydwanach dwukołowych lub wozach jak Galowie. Wozy, które mają przy osiach kosy, nazywają kowiny”. Z kolei Syliusz Italikus pisze, że „Thule [Bryt - B.S.] gdy walczy, przejeżdża swym rydwanem z ostrzami na kołach (covinnus) przez zwarte szyki, rozbijając je" ${ }^{\prime 33}$. T. Newark sądzi, że jest to jedynie reminiscencja nawiązująca do perskiej i syryjskiej praktyki wykorzystywania $\mathrm{w}$ walce rydwanów $\mathrm{z}$ kosami, nieznajdująca potwierdzenia $\mathrm{w}$ materiale archeologicznym pozyskanym na terenie Celtyki ${ }^{34}$. Kłóci się to jednak z popularnym na Wyspach stereotypem odzwierciedlonym na pomniku, który przedstawia Boudikę w towarzystwie córek na rydwanie z kosami. Pomnik odsłonięty w 1902 roku

\footnotetext{
${ }^{29}$ Flor. I, 37.

${ }^{30}$ R.L. Jimenez, Caesar against the Celts..., s. 103; J.H. Crouwel, Chariots..., s. 112. Woźnica najczęściej powoził nudo corpore, z odsłoniętym ciałem.

${ }^{31}$ Mart., Epigr. XII, 24 (przeł. S. Kołodziejczyk); R.L. Jimenez, Caesar against the Celts..., s. 103.

${ }^{32}$ Luc., Phars. I, 426; Mart., Epigr. XII, 24; Frontin., Str. II, 3, 18. Ten ostatni autor twierdzi, że Cezar widział takie pojazdy w Galii.

${ }_{33}$ Pomp. Mel. III, 6; Sil. Ital. XVII, 418-419.

${ }^{34}$ T. Newark, Warlords..., s. 162; A. Cotterell, Chariot, Woodstock, New York 2005, s. 140; W.E. Ritchie, J.N.G. Ritchie, Celtic Warrior..., s. 33-34; J. Wileman, Warfare in Northern Europe..., s. 137.
} 
znajduje się na północnym końcu Westminster Bridge. Jakkolwiek brak przesłanek archeologicznych do uznania tego typu pojazdów za broń z arsenału Celtów, to jednak autorytatywnie wykluczyć takiej możliwości się nie da. Zwłaszcza jeśli weźmie się pod uwagę przekazy literackie, a przede wszystkim obecność Celtów w charakterze najemników na Bliskim Wschodzie, gdzie mieli możność zapoznania się z tymi rydwanami, a może nawet wejścia w ich posiadanie. Należy też raz jeszcze zwrócić uwagę na fragment tekstu Pomponiusza, który pisze o walce na rydwanach w stylu galijskim, co może sugerować użycie kos na kontynencie, jak twierdzi Frontinus. Sama technika walki opisana przez Syliusza też nie budzi większych zastrzeżeń i wskazuje na znajomość rzeczy, chociaż pewną wątpliwość budzić może domniemana skuteczność działania.

Tradycyjne rydwany znakomicie spisały się w starciu z legionami Cezara, czyli w konfrontacji - jak to ujął Todd Carey - anachronizmu rodem z epoki brązu z najlepszą armią epoki żelaza ${ }^{35}$. Był to wynik nałożenia się na siebie kilku okoliczności: słabej znajomości realiów pola walki przez Rzymian, dynamiki działań Brytów wykorzystujących rzeźbę terenu oraz harmonijnego współdziałania ich piechoty z jazdą i rydwanami. Te ostatnie mocno oddziaływały psychologicznie na legionistów - przez zastraszenie hałasem oraz impet szarży wywoływały panikę w szeregach ${ }^{36}$. Nie oznacza to jednak, że z upływem czasu Rzymianie nie wypracowali odpowiedniej taktyki. Wszystko wskazuje na to, że receptą na sukces w starciu z Brytami stał się grad pilów miotanych z krótkiego dystansu zza muru tarcz. Doświadczenie nabyte tą drogą zaowocowało w bitwie pod Zelą w 47 roku p.n.e., gdzie Cezar unieszkodliwił rydwany z kosami króla Farnakesa, oraz wiek później - w walce z siłami Boudiki ${ }^{37}$.

Ostatnim rozdziałem dziejów tego archaicznego narzędzia walki był udział w masie w bitwie plemion kaledońskich z wojskami Gnejusza Juliusza Agrykoli pod Mons Graupius w 83 roku n.e. Również w tym starciu rydwany celtyckie nie odegrały znaczącej roli rozproszone przez jazdę rzymską i metodycznie niszczone przez piechotę, na co wskazuje wzmianka o błąkających się po polu bitwy rydwanach bez załogi ${ }^{38}$. Potwierdza to tezę, że w tamtym czasie nie stanowiły już poważnego zagrożenia na polu bitwy. Znakomicie ujął to Wegecjusz, pisząc, że rydwany „Z początku wywoływały ogromny strach, ale po chwili stawały się obiektem drwin, bowiem rydwan wymaga równej drogi, którą trudno znaleźć, i zatrzymuje się na byle nierównościach. Staje się też bezużyteczny, gdy chociaż jeden koń zostaje ranny

${ }^{35}$ B. Todd Carey, Warfare in the Ancient World, Barnsley 2005, s. 130.

${ }^{36}$ M.N. Faszcza, Rzymskie inwazje na Brytanię..., s. 60; The Ancient World at War, ed. P. de Souza, London, New York 2008; Rome and her Enemies..., s. 137; S. Allen, Celtic Warrior 300 BC-AD 100, Oxford 2001, s. 48.

${ }^{37}$ Cass. Dio XVII, 47,5; BAlex. 75; Tac., Ann. XIV, 36-37.

38 Tac., Agr. 36; D.B.Campbell, Bitwa pod Mons Graupius, Poznań 2011, s. 79. 
lub osłabnie" 39 . Nieadekwatna do rzymskiego sposobu wojowania taktyka walki wyeliminowała je $\mathrm{z}$ arsenału środków bojowych, odsyłając do muzeum historii wojskowości, czyli tam, gdzie od dawna było ich miejsce.

\section{Bibliografia}

Allen S., Celtic Warrior 300 BC-AD 100, Oxford 2001.

The Ancient World at War, ed. P. de Souza, London, New York 2008.

Anglim S. et al., Fighting Techniques of the Ancient World, London 2002.

Banfi G., L’Armamento dei Celti, Rimini 2004.

Campbell D.B., Bitwa pod Mons Graupius, przeł. N. Łajszczak, Poznań 2011.

Castleden R., Wojna trojańska, przeł. B. Tkaczow, Warszawa 2008.

Cotterell A., Chariot, Woodstock, New York 2005.

Crouwel J.H., Chariots and other wheeled vehicles, Oxford 2012.

D'Amato R., Bronze Age Greek Warrior 1600-1100 BC, Oxford 2011.

D’Amato R., Early Iron Age Greek Warrior 1100-700 BC, Oxford 2016.

Deyber A., Les Gaulois en guerre, Paris 2009.

Faszcza M.N., Rzymskie inwazje na Brytanię 55-54 p.n.e., Zabrze 2012.

Ferrill A., The Origins of War, London 1985.

Hamblin W.J., Warfare in the Ancient Near East to 1600 BC, Routledge 2006.

Harrison P., Great Battles of the Ancient World, London 2004.

Jimenez R.L., Caesar against the Celts, Kent 1996.

Mathieu F., Le guerrier gaulois, Paris 2012.

Mieroop M. van de, Historia starożytnego Bliskiego Wschodu, przeł. M. Komorowska, Kraków 2008.

Millard A., Going to War in Ancient Egypt, London 2000.

Newark T., Warlords, London 1996.

Newark T., Ancient Celts, Concord 1997.

Oorthuys J., Warfare in the Ancient Near East, „Ancient Warfare” 2008, 2, 5, s. 6-7.

Riemschneider M., Od Olimpii do Niniwy w epoce Homera, przeł. F. Przebinda, Warszawa 1969.

Ritchie W.E., Ritchie J.N.G., Celtic Warrior, Aylesbury 1985.

Rome and her Enemies, ed. J. Penrose, Oxford 2008.

Taratorin W.W., Konnica na wajnie. Istorija kawalerii s drewniejszych wremion do epochy napoleonowskich woin, Minsk 1999.

Todd Carey B., Warfare in the Ancient World, Barnsley 2005.

Wileman J., Warfare in Northern Europe before the Romans, Barnsley 2014.

${ }^{39}$ Veg. III, 24 (przeł. M. Komornicka). 
Bronisław Szubelak

\section{The Celtic Chariot in the Era of the Caesarian Wars}

Summary

The use of chariots in warfare had a long tradition in the ancient Near East, but not in northern Europe. In many regions, chariots and the horses that pulled them were interred with wealthy leaders in their tombs. Chariots were common in Europe until around $100 \mathrm{BCE}$, although they continued to be used for much longer in Britain. Their speed and agility caused serious difficulties for the Roman infantry. Chariots were not intended to charge headlong into enemy formations. The warrior was able to fight against horsemen from the chariot's platform, but would dismount to fight infantry soldiers on foot. In the meantime, the charioteer would move away a short distance from the battle, waiting to collect the warrior and carry him to safety, if necessary. A typical British chariot consisted of a small platform, open in the front and in the back, mounted on a wooden axle and with wheels made strong by iron tires. The charioteers sat at the front of the platform between two sideboards made of wood or wickerwork. However, the double arcade seems to be the most convincing interpretation of the evidence found on coins. In Britain, most horses were the size of the modern Dartmoor ponies and were effective in pulling chariots. The continental Gauls learned to breed larger horses capable of carrying a warrior and his weapon. The war-chariot of the Britons almost certainly did not have scythes. There is no accepted archaeological evidence concerning scythed chariots.

Key words: British chariot, scythed chariot, pony, warrior, charioteer 